\title{
Investigating the Industrial Potentials of Some Selected Nigerian Clay Deposits
}

\author{
Lydia Solomon Jongs ${ }^{1}$, Alexander Asanja Jock ${ }^{2 *}$, Okon Eno Ekanem ${ }^{3}$, Aliyu Jauro ${ }^{3}$ \\ ${ }^{1}$ National Metallurgical Development Centre, Jos, Nigeria \\ ${ }^{2}$ Chemical \& Petroleum Techniques, Department of Science Laboratory Technology, University of Jos, Jos, Nigeria \\ ${ }^{3}$ Department of Chemistry, Abubakar Tafawa Balewa University, Bauchi, Nigeria \\ Email: ^alsanja@gmail.com
}

How to cite this paper: Jongs, L.S., Jock, A.A., Ekanem, O.E. and Jauro, A. (2018) Investigating the Industrial Potentials of Some Selected Nigerian Clay Deposits. Journal of Minerals and Materials Characterization and Engineering, 6, 569-586. https://doi.org/10.4236/jmmce.2018.66041

Received: October 8, 2018

Accepted: November 12, 2018

Published: November 15, 2018

Copyright (C) 2018 by authors and Scientific Research Publishing Inc. This work is licensed under the Creative Commons Attribution International License (CC BY 4.0).

http://creativecommons.org/licenses/by/4.0/

\begin{abstract}
One of the most important useful and widely abundant industrial minerals in the world is the clay minerals. Their applications in various industries are dependent on their properties. In this study, the mineralogical and physico-chemical properties of RahinSho (RC), Major Porter (MP), Wereng camp (WC), Kwi (KC) and Naraguta (NC) clay deposits in Plateau State, Nigeria were investigated to evaluate their potentials for some industrial uses. The $\mathrm{x}$-ray diffraction studies revealed the kaolins as the dominant clay minerals in all the samples. The non-clay minerals found were quartz and muscovite. The chemical analyses by $\mathrm{x}$-ray fluorescence also indicated that the silica $\left(\mathrm{SiO}_{2}\right)$ values of the samples ranged from $(41.20-62.26) \%$ while the alumina $\left(\mathrm{Al}_{2} \mathrm{O}_{3}\right)$ range was $(17.25-37.15) \%$. Some considerable amounts of impurities found were $\mathrm{Fe}_{2} \mathrm{O}_{3}(0.43-27.52) \%, \mathrm{TiO}_{2}(0.05-3.28) \%, \mathrm{~K}_{2} \mathrm{O}(0.13-3.01) \%$. The oxides of $\mathrm{Na}, \mathrm{Ca}$ and $\mathrm{Mg}$ were within acceptable limits in the clays for most purposes. The loss on ignition ranged from $4.30 \%-12.43 \%$. The physical properties investigated were particle size distribution that contained heavy clay-size materials ranging from $67.88 \%$ - $91.88 \%$, plasticity index had range of values from $15.90 \%-33.68 \%$, and drying and firing shrinkages were $1.10 \%-2.22 \%$ and $1.65 \%-4.49 \%$ respectively. All the samples attained a temperature of $1500^{\circ} \mathrm{C}$ without fusion except Naraguta clay that fused at $1300^{\circ} \mathrm{C}$. At the temperature of $1200^{\circ} \mathrm{C}, \mathrm{RC}, \mathrm{MP}$ and WC clays retained their natural colours of white and near-white respectively, while $\mathrm{KC}$ and $\mathrm{NC}$ clays changed colours from orange pink and light brown to moderate pink and moderate reddish brown respectively. These results compare very well with several clays elsewhere. Based on these characteristics, the clays were observed to be potentially suitable for the production of paints, tiles, ceramics, refractories, sanitary wares and clay bricks. Minimal processing will increase the potential of RC and MP to meet up with specification for paper, fertilizer and/or pharmaceutical uses.
\end{abstract}




\section{Keywords}

Clay, Deposit, Characterization, Industries

\section{Introduction}

Clay deposits contain clay minerals, which are essentially hydrated aluminium silicates and are usually in association with non-clay minerals such as quartz, feldspar, mica, calcite, and so on [1]. Common clay mineral groups are the kaolins, smectites, chlorites, illites, mixed-layered and others. Clay minerals have been mined and used for pottery and bricks since the Stone Age. Today, they are amongst the most important minerals used by environmental, manufacturing and process industries [2]. The properties of the clay minerals differ greatly amongst themselves because of differences in structure and compositions, and that each group has different applications because of the differences in their physical and chemical properties [3]. The mineral content of these deposits can be identified by $\mathrm{x}$-ray diffraction.

Clay is an abundant raw material. Its exceptional and some specific properties lead to various industrial applications that depend also on its dispersions and rheological properties, the presence of organic materials and impurities, type and amount of exchangeable ions and soluble salts, and textural properties [4]. Plasticity is one of the most important clay properties that are related to different parameters. The most disaggregated clay minerals with major ionic exchange capability are more plastic. Montmorillonitic minerals are most plastic, then illitics, and least kaolinitics. In each of this group exists significant variability of characteristics, crystalline structures, particle size distribution and specific surface, with a major capability to absorb water [5]. The ability of clay minerals to attract strongly water molecules to form a slurry and mud is used in the paint and pottery/ceramic industries as a carrier and shaping of ceramic products respectively [2].

The industrial utilization of a clay deposit depends on its geological, mineralogical, chemical and physical properties. The assessment of economic potentialities of a clay body must involve the evaluation of the separameters [6]. Some of the commonest and important applications of clays are in the manufacture of paper, paint, plastics, ink, roofing sheets, pottery, bricks, ceramics, floor tiles and rubber. Clays also find various applications in the manufacture of cement, fertilizers and insecticides [7]. They are used in advanced chemical processing because of their reactivity and catalytic activity [8]. Clays are also utilized in pharmaceuticals and food processing industries [9]. Some of these applications require the processing or the blending with other materials so as to improve on some desired characteristics of the finished product [10].

Numerous studies exist on clay deposits that are widely spread in Africa and especially Nigeria [11], [12]. Some clay deposits in Nigeria have been investi- 
gated for various applications. The clay deposits in Cross Rivers State have been evaluated and found potentially suitable for the manufacture of bricks, refractories, tiles and pottery [13] [14] [15]. Also, tests on clay deposits in Onibode, Ijopo in Ogun State and Are-Ekiti State revealed that their properties compare favorably with imported refractories [16]. The mineralogical, physical, geochemical and economic appraisals of some clay and shale deposits in South Western and North Eastern Nigeria have been discussed [10]. Clay deposits as Giru in Kebbi State, Kankara in Katsina State and Darazo in Bauchi State have been reported to have required properties by the Raw Materials Research and Development Council [17] and National Metallurgical Development Centre, Jos [18]. In this study, clay deposits from RahinSho, Major Porter, Wereng Camp, Kwi and Naraguta in Plateau State, Central Nigeria were characterized for some physical, chemical and mineralogical compositions with the view of determining their industrial applications.

The results of this characterization shows that the samples of NC and KC cannot be used as refractory clays but suitable for the production of building bricks and sewer pipes while RC, MP and WC suggests their applications in the paper, paint, ceramic, sanitary and tile industries.

\section{Materials and Methods}

\subsection{Sample Collection and Preparation}

Clay samples were collected from five different locations inthe Upper part of Plateau State, Central Nigeria. RahinSho and Major Porter deposits are located in Barkin Ladi, Kwi and Wereng Camp clay deposits are in Riyom, while Naraguta deposit is located in Jos North Local Government Area as shown in Figure 1. The study areas are bounded between latitudes $8^{\circ} 30 \mathrm{E}$ and $9^{\circ} 00 \mathrm{E}$ and longitudes $9^{\circ} 30 \mathrm{~N}$ and $10^{\circ} 00 \mathrm{~N}$.

$5 \mathrm{~kg}$ of fresh samples in lump form were obtained randomly from ten different points within each deposit from underground local mines pit at the depth of $10-20 \mathrm{~cm}$. The samples were air-dried for several days and crushed using a set of Denver crushers by Denver Equipment Co. England. Each crushed sample was thoroughly mixed, coned and quartered. Two opposite composite representatives were obtained and consequently milled and pulverized. These were packaged in small polyethene bags as representatives of the samples for the required tests [19].

\subsection{Methods of Analysis}

\subsubsection{Mineralogical and Chemical Properties of Clay Samples}

X-ray diffraction

The identification of clay minerals of each clay sample was carried out using a Panalytical BV Empyrean PW 1800 X-ray diffractometer. All pulverized samples of $(1.5 \mu \mathrm{m})$ size were oven-dried and about $0.5 \mathrm{~g}$ of each was mounted and analyzed using a copper $(\mathrm{Cu})$ target radiation at $45 \mathrm{KV}$ and $20 \mathrm{~mA}$ at the scan speed 


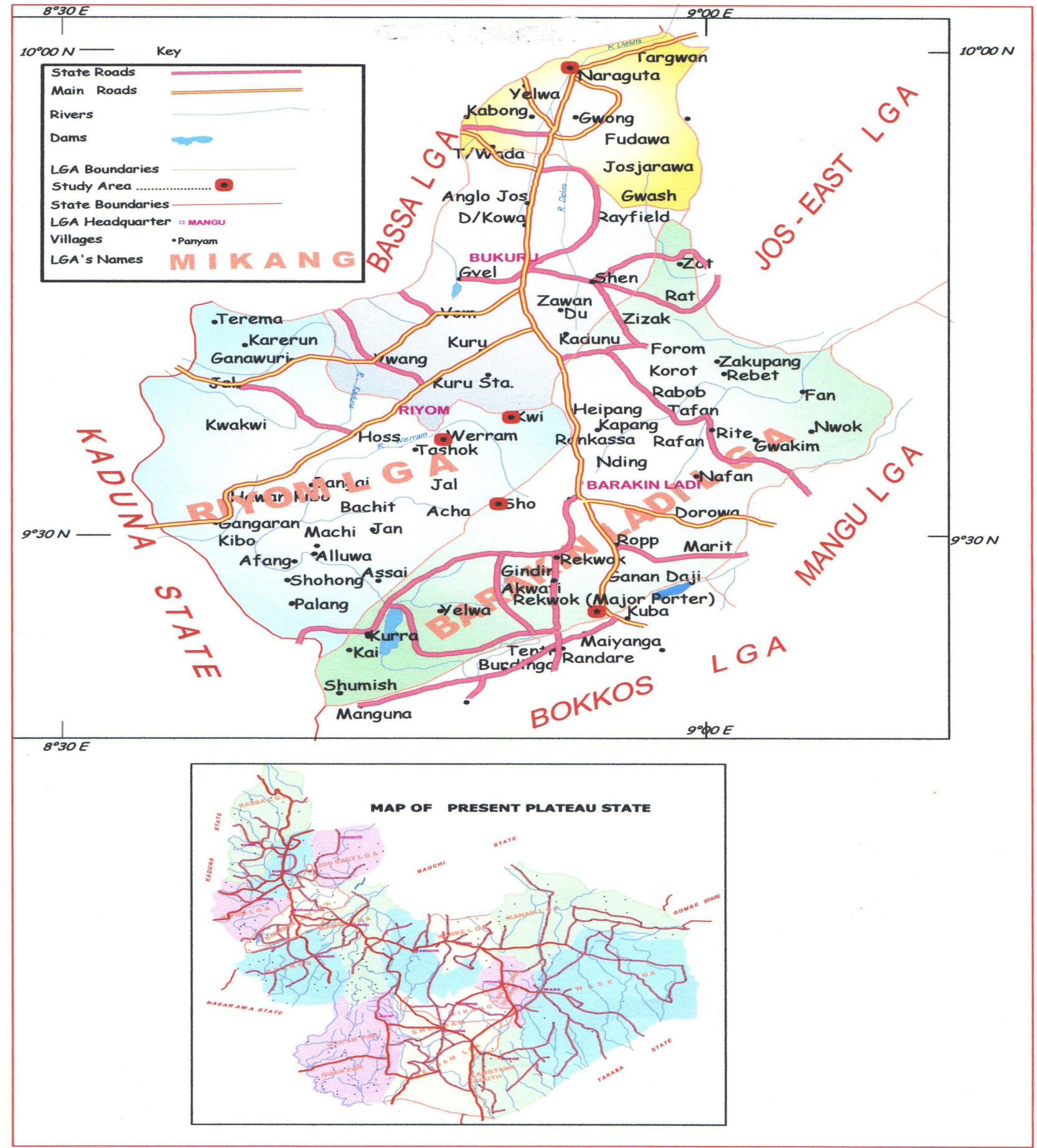

Figure 1. Map of the study sites [adapted from Ministry of Land and Survey, Plateau State].

of $2^{\circ}$ per minute. The interpretation of the diffractograms obtained for each sample was done by comparing the peaks with those of standard minerals [20].

$\mathrm{X}$-ray fluorescence

The chemical compositions of the pulverized samples were determined by Energy Dispersive X-ray Fluorescence (EDXRF) of the model PW4030 X-ray photometer that uses a rhodium anode tube. The sample film was placed firmly 
in a waxed and gold plated sample holder. The Energy Dispersive patterns were obtained with the help of a computer attached to the instrument and each compound recorded in percentage [21].

Loss on ignition

Loss on ignition was determined according to the Lechler and Desiletes method, [22]. The samples were oven-dried at $110^{\circ} \mathrm{C}$. Then $1 \mathrm{~g}$ of the sample of clays was placed in preheated, cooled and pre-weighed silica crucibles and heated to $1000^{\circ} \mathrm{C}$ in a furnace for an hour. The crucibles and contents were removed, cooled in a desiccator to room temperature and weighed again. The loss in weight was calculated.

\subsubsection{Physical and Thermal Properties of Clay Samples \\ Clay $\mathrm{pH}$}

The clays $\mathrm{pH}$ were determined using the Rex $\mathrm{pH}$ Meter (model $\mathrm{pHS}-25$ ) and the procedure adopted according to [23]. The clay to water ratio was $1: 5 \mathrm{w} / \mathrm{v}$ and the $\mathrm{pH}$ meter was calibrated with buffer solutions of $\mathrm{pH} 9.2,7.0$ and 4.0. The $\mathrm{pH}$ of each sample was read and recorded at room temperature.

\section{Plasticity index of clay samples}

The Atterberg plasticity method prescribed by [24] was used to calculate the plasticity index of the clay samples from their respective liquid and plastic limits determined.

\section{Particle-size analysis}

The particle size test was carried out by using the standard Hydrometer method [23]. $50 \mathrm{~g}$ of milled oven-dry clay was weighed into a $250 \mathrm{~cm}^{3}$ beakers and mixed with $100 \mathrm{~cm}^{3}$ calgon, then allowed to soak for 30 minutes. The mixed suspension was transferred into a sedimentation cylinder and filled up to mark point with distilled water.

The hydrometer was inserted into the mixture in the cylinder and the readings were taken after interval of 40 seconds twice. After 2 hours, another hydrometer reading and temperature were recorded. After 40 seconds and 2 hours, all the sand and silt particles would have settled and only clay will remain in suspension. The percentages silt and clay were then calculated and the interpretation of result was made by using a textural triangle.

\section{Drying and firing shrinkage of clays}

The clay drying and firing shrinkages were determined from brick bars prepared using a mechanical hydraulic press (model D-7064 Paul Weber) with its accessory moulds and the method adopted was [25].

\section{Refractoriness of clay samples}

Fired clay bricks were used to estimate the refractoriness of the clay samples according to the procedure by [26]. Square shape pieces were cut with a hacksaw from the fired bricks made from different clay samples. The samples were fired in a carbolite furnace Model RHF 1600 at the rate of $5^{\circ} \mathrm{C}$ per second at the temperatures ranging between $1300^{\circ} \mathrm{C}$ and $1500^{\circ} \mathrm{C}$. The piece that fuses at any of the temperature was taken to be the fusion point and thereby its refractoriness. 


\section{Colour test of clay samples}

The colour of the clay samples were determined by using the American Rock-Colour Chart Test. The colours of both the raw and fired clays were ascertained by comparing with that of the chart based on the Munsell charts plot according to the method [27].

\section{Results and Discussion}

\subsection{Mineralogical Composition of the Clays}

The mineralogical composition of the clays determined using X-ray powdered diffraction is presented in Table 1 and the diffractograms shown in Figures 2-6. The samples were scanned at a position of $0^{\circ}-40^{\circ}$ of 2 -theta angle using a copper element target showed several peaks with respect to the different minerals found in each sample.

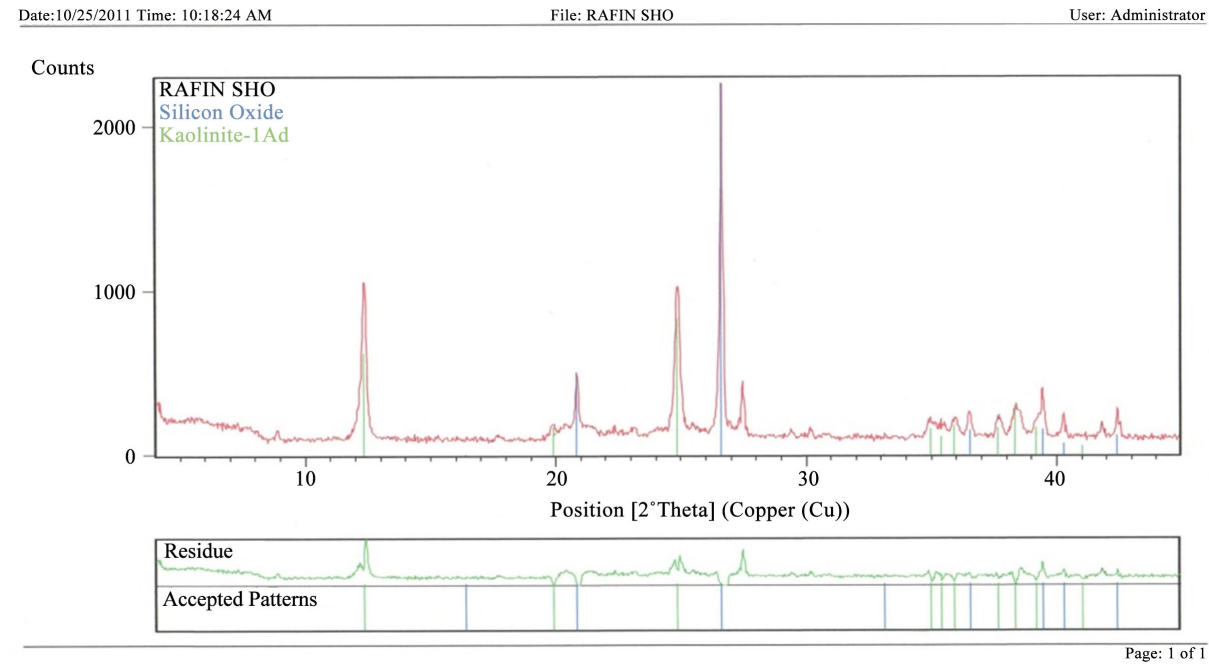

Figure 2. X-ray diffractogram of RahinSho sample.

Date: 11/23/2011 Tme: 12:57:38 PM File: MPC User: Administrator

Counts

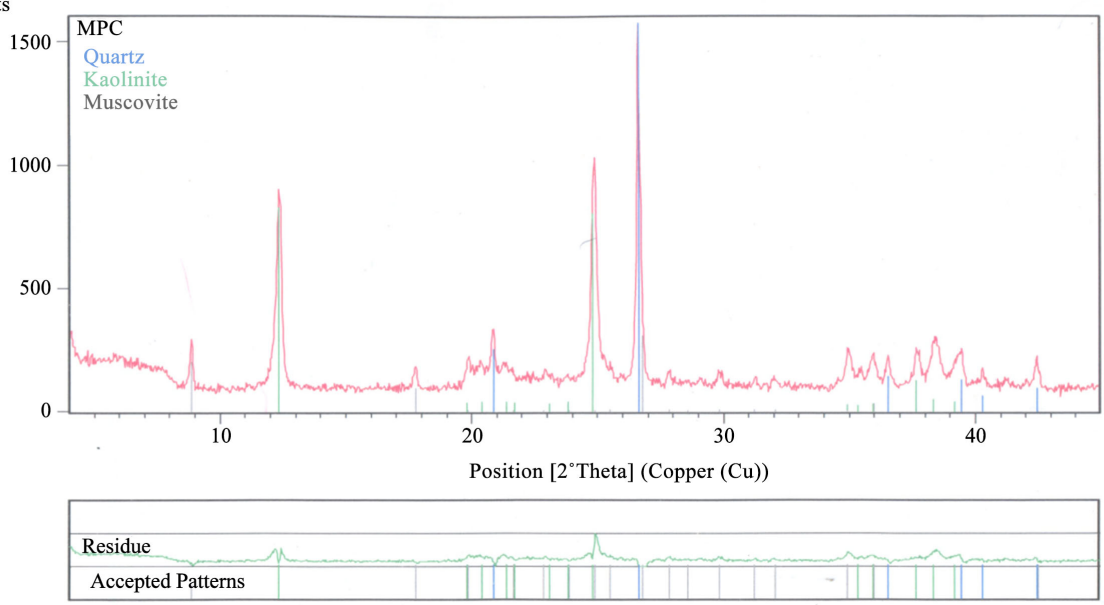

Accepted Patterns

Figure 3. X-ray diffractogram of Major Porter sample. 
Count
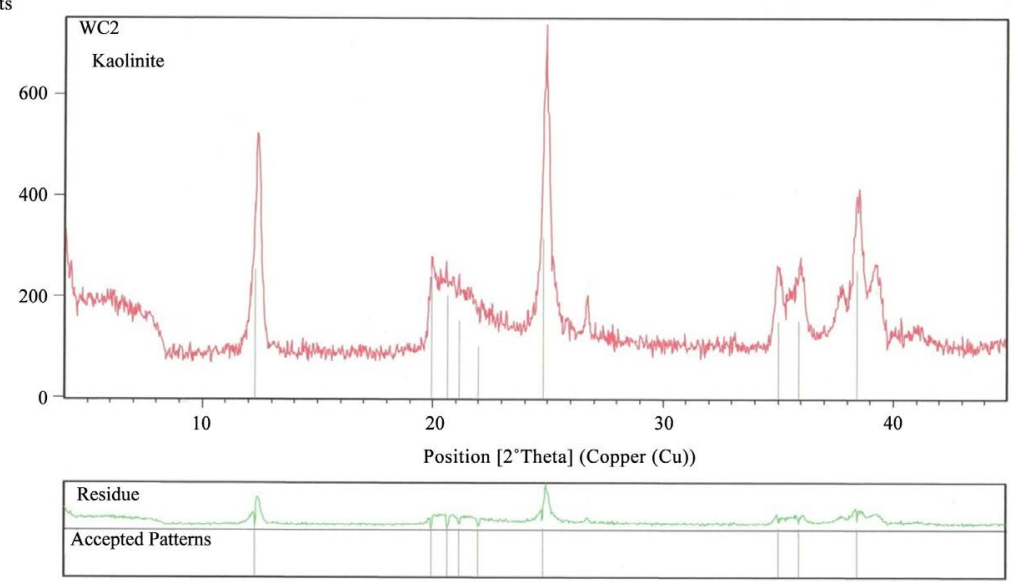

Page: 1 of 1

Figure 4. X-ray diffractogram of Wereng Camp sample.

Date: 11/23/2011 Time: 12:54:47 PM File: KC User: Administrator

Counts
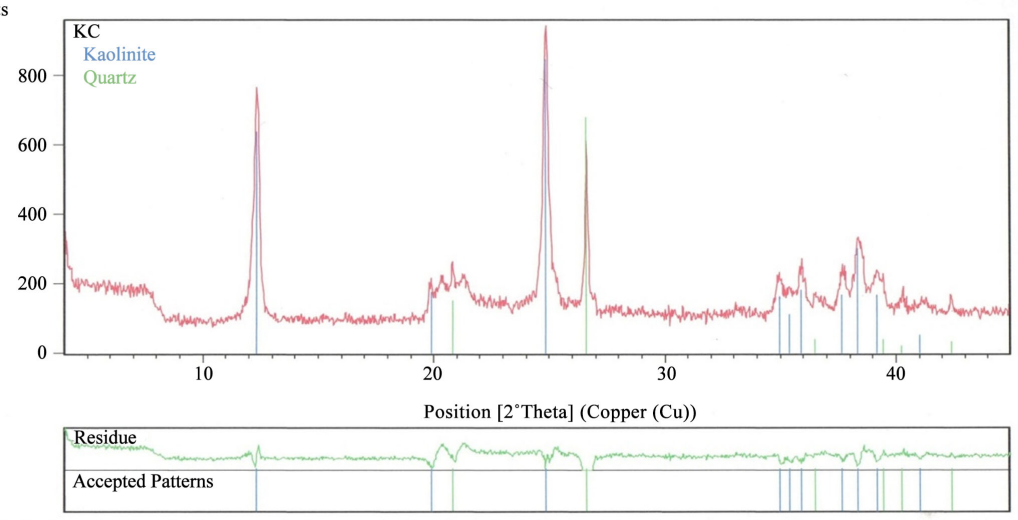

Page: 1 of 1

Figure 5. X-ray diffractogram of Kwi clay sample.

Date: 11/23/2011 Time: 1:00:37 PM File: $\mathrm{NC}$ User: Administrator

Counts
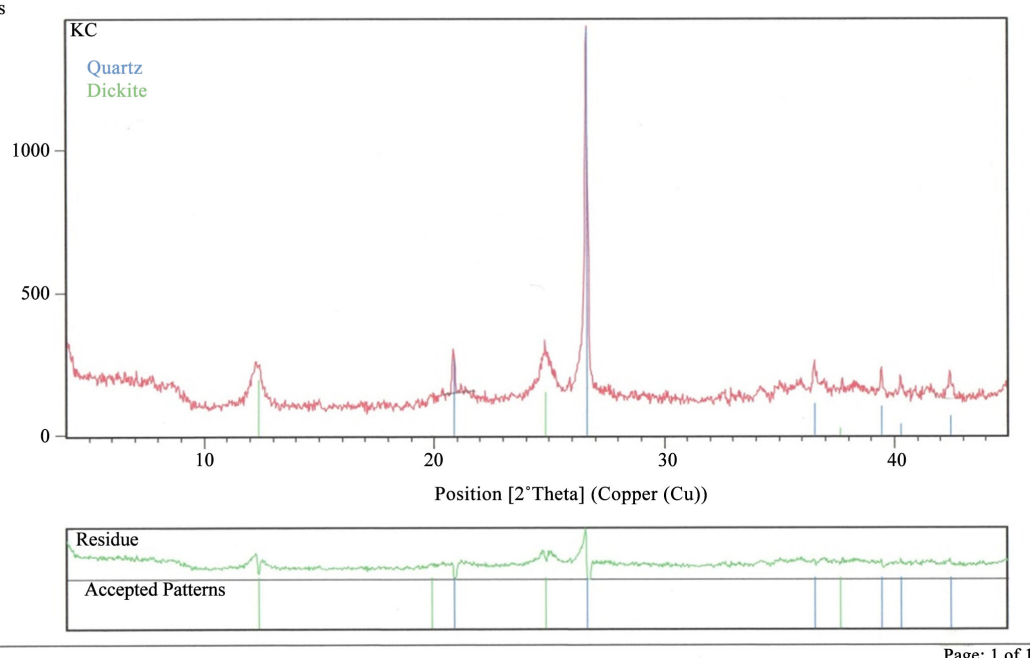

Figure 6. X-ray diffractogram of Naraguta clay sample. 
Table 1. Mineralogical compositions of the clay samples and some reference clay materials.

\begin{tabular}{|c|c|c|c|c|c|c|c|c|c|}
\hline \multirow{2}{*}{$\begin{array}{l}\text { Minerals } \\
(\%)\end{array}$} & \multirow[b]{2}{*}{ RahinSho Clay } & \multirow{2}{*}{$\begin{array}{c}\text { Major } \\
\text { Porter Clay }\end{array}$} & \multirow{2}{*}{$\begin{array}{c}\text { Wereng } \\
\text { Camp Clay }\end{array}$} & \multirow{2}{*}{$\begin{array}{l}\text { Kwi } \\
\text { Clay }\end{array}$} & \multirow{2}{*}{$\begin{array}{c}\text { Nara-guta } \\
\text { Clay }\end{array}$} & \multicolumn{4}{|c|}{ Reference clays } \\
\hline & & & & & & $\begin{array}{l}\text { *Ibadan } \\
\text { Clay }\end{array}$ & $\begin{array}{c}\text { *an-kara } \\
\text { Clay }\end{array}$ & $\begin{array}{c}{ }^{* *} \text { China } \\
\text { Clay }\end{array}$ & $\begin{array}{c}{ }^{\wedge} \text { NAFCON } \\
\text { Recommended }\end{array}$ \\
\hline Kaolinite & 56.24 & 41.40 & 98.11 & 87.99 & - & 91 & 96 & 85 & 85 \\
\hline Dickite & - & - & - & - & 17.93 & - & - & - & - \\
\hline Illite & - & - & - & - & - & 3 & 3 & 15 & 3 \\
\hline Quartz & 39.70 & 30.45 & - & 12.01 & 82.07 & 6 & 2 & $\operatorname{Tr}$ & 4 \\
\hline Muscovite & - & 28.16 & - & - & - & - & - & - & - \\
\hline Felspar & - & - & - & - & - & - & - & - & 2 \\
\hline Others & 4.05 & - & 1.89 & - & - & - & - & - & 8 \\
\hline Total & 99.99 & 100.01 & 100.00 & 100.00 & 100.00 & 100.00 & 99.00 & 100 & 98 \\
\hline
\end{tabular}

*[28]; **[29]; ${ }^{\wedge}[30] ; \operatorname{Tr}=$ trace.

The results indicate that the samples were composed of different types of minerals. The kaolin group of clay minerals is most predominant, while the main non-clay minerals are quartz and muscovite.

Kaolinite type of mineral was found in RahinSho (RC), Major Porter (MP), Wareng Camp (WC) and Kwi Clay (KC) deposits, while the dickite type was found in Naraguta Clay (NC) deposits. The main non-clay minerals are quartz found in varying proportions in all deposits except WC sample and muscovite found only in MP sample.

Clays are particularly noted to contain many mineral types, and are very diverse in composition. Many of their properties depend on the nature and amounts of the various minerals present. The analysis of the clay samples in Table 1 shows that the proportion of the predominant clay mineral kaolins are in the order: WC $(98.11 \%)>\mathrm{KC}(87.88 \%)>\mathrm{RC}(56.24 \%)>\mathrm{MP}(41.40 \%)>\mathrm{NC}$ (17.93\%) while quartz varies from $12.01 \%$ to $82.07 \%$, muscovite has a value of $28.16 \%$ and other minerals range from $1.89 \%$ to $4.05 \%$.

Quartz and muscovite are found in high proportion in these clays and this indicates that all the clay samples formed at the deposits are either of residual weathering or hydrothermal formation. Such clay minerals are formed as alteration products associated with geothermal areas and hot springs, and as aureoles around hydrothermal ore deposits This type of kaolin clays undergo little or no transportation and usually contain a much larger proportion of primary minerals [1]. The identification of the kaolinite type of mineral in RC, MP, WC and $\mathrm{KC}$ samples as shown in Figures 2-5 suggests formation from weathering process which involves physical disaggregation and chemical decomposition that change original minerals to clay minerals. Kaolinite is found in most weathering zones and soil profiles [2].

The proportion of dickite, one of the two well-formed of all kaolin mineral found in NC sample was quite low (17.93\%). The occurrence of this mineral type 
is not common but mainly formed as a product of acid hydrothermal fluids. It is also occasionally found in iron beds as a white powder in cavities and center of noodles [31]. This explains the reason for the very high content of iron oxide in this deposit as observed from the chemical analysis. The absence of primary minerals in WC clay also explains the reason for the corresponding high proportion of its clay minerals at $98.11 \%$.

\subsection{Chemical Analysis of the Samples}

The result of the chemical analysis summarized in Table 2 shows that all the samples contain $\mathrm{SiO}_{2}$ and $\mathrm{Al}_{2} \mathrm{O}_{3}$ as the major components. Silica ranged from $41.20 \%$ - $62.26 \%$, alumina (17.25\% - 37.15\%) and LOI (4.3\% to $12.43 \%)$, while $\mathrm{Fe}_{2} \mathrm{O}_{3}, \mathrm{TiO}_{2}$ and $\mathrm{K}_{2} \mathrm{O}$ were in moderate to major concentration levels.

The high amounts of $\mathrm{SiO}_{2}, \mathrm{Al}_{2} \mathrm{O}_{3}$ and LOI define the clay samples as hydrated alumino-silicate type of minerals [26]. This is attributed to the fact that kaolin clays are principally composed of $\mathrm{SiO}_{2}, \mathrm{Al}_{2} \mathrm{O}_{3}$ and water, which have a chemical composition of $\mathrm{Al}_{2} \mathrm{Si}_{2} \mathrm{O}_{5}(\mathrm{OH})_{4}$, also represented as $\mathrm{Al}_{2} \mathrm{O}_{3} \cdot 2 \mathrm{SiO}_{2} \cdot 2 \mathrm{H}_{2} \mathrm{O}$. The average $\mathrm{SiO}_{2}, \mathrm{Al}_{2} \mathrm{O}_{3}$ and water contents in the clay samples constitute about $96.08 \%$ for( RC) clay, $95.05 \%$ for (MP) clay, $95.68 \%$ for (WC) clay, $90.03 \%$ for (KC) and $63.58 \%$ for (NC) samples.

In most samples, $\mathrm{SiO}_{2}$ and $\mathrm{Al}_{2} \mathrm{O}_{3}$ are the distinctive major constituents. The only exception is observed with $\mathrm{NC}$ clay that has very high $\mathrm{Fe}_{2} \mathrm{O}_{3}$ of approximately $28 \%$ and the $\mathrm{Al}_{2} \mathrm{O}_{3}$ content $(17 \%)$ is much lower than in other samples. This explains the probable reasons for the low value of the clay mineral of $\mathrm{Na}$ raguta clay shown in Table 1 . However, the high amounts of the $\mathrm{SiO}_{2}, \mathrm{Al}_{2} \mathrm{O}_{3}$ and $\mathrm{Fe}_{2} \mathrm{O}_{3}$ in some of the samples suggest that the clays could be used for a variety of purposes [19]

Table 2. Chemical composition of clay samples.

\begin{tabular}{|c|c|c|c|c|c|}
\hline Oxides (\%) & $\begin{array}{c}\text { RahinSho Clay } \\
\text { (RC) }\end{array}$ & $\begin{array}{l}\text { Major Porter } \\
\text { Clay (MP) }\end{array}$ & $\begin{array}{c}\text { Wereng Camp } \\
\text { Clay } \\
\text { (WC) }\end{array}$ & $\begin{array}{l}\text { Kwi Clay } \\
(\mathrm{KC})\end{array}$ & $\begin{array}{c}\text { Naraguta Clay } \\
\text { (NC) }\end{array}$ \\
\hline $\mathrm{SiO}_{2}$ & 62.26 & 55.10 & 50.15 & 46.48 & 41.20 \\
\hline $\mathrm{Al}_{2} \mathrm{O}_{3}$ & 29.44 & 34.73 & 37.15 & 31.12 & 17.25 \\
\hline $\mathrm{Fe}_{2} \mathrm{O}_{3}$ & 0.43 & 1.39 & 1.93 & 5.54 & 27.52 \\
\hline $\mathrm{TiO}_{2}$ & 0.05 & 1.54 & 2.82 & 3.10 & 3.28 \\
\hline $\mathrm{Na}_{2} \mathrm{O}$ & 0.13 & 0.23 & 0.08 & 0.12 & 1.17 \\
\hline $\mathrm{K}_{2} \mathrm{O}$ & 2.19 & 1.97 & 0.13 & 0.33 & 3.10 \\
\hline $\mathrm{CaO}$ & 0.46 & 0.43 & 0.06 & 0.23 & 0.33 \\
\hline $\mathrm{MgO}$ & 0.33 & 0.15 & 0.07 & 0.14 & 0.57 \\
\hline LOl & 4.30 & 5.22 & 8.38 & 12.43 & 5.13 \\
\hline
\end{tabular}


The results of the chemical analysis show that the clay samples have $\mathrm{SiO}_{2}$ content in the order RC $(62.26 \%)>\mathrm{MP}(55.10 \%)>\mathrm{WC}(50.15 \%)>\mathrm{KC}(46.48 \%)>$ NC (41.20\%). These values except for KC and NC are slightly above the ideal $\mathrm{SiO}_{2}$ value of pure kaolinites (46.54\%) [32]. The deviation suggests the presence of free $\mathrm{SiO}_{2}$ as crystalline quartz usually occurring in residual clays or in combination with other compounds as impurities of fluxes, feldspar or mica [33]. This could also be attributed to the high amount of quartz and muscovite found from the mineralogical compositions of RC and MP samples. Free quartz and high $\mathrm{SiO}_{2}$ affect clays by reducing physical properties such as plasticity, crushing strength, refractoriness in many cases, and also the drying and firing shrinkages [31].

The $\mathrm{Al}_{2} \mathrm{O}_{3}$ content also follows the order: $\mathrm{WC}(37.15 \%)>\mathrm{MP}(34.73 \%)>\mathrm{KC}$ $(31.12 \%)>\mathrm{RC}(29.44)>\mathrm{NC}(17.25 \%)$. WC, MP and KC samples reflect values close to that of pure kaolinite with $39.50 \%$ which also indicates the quality of the pure clay minerals [26]. The higher the $\mathrm{Al}_{2} \mathrm{O}_{3}$ content of clay, the higher its refractoriness and a good range is between $25 \%-45 \%$ [34]. This shows that all the clay samples except NC have a moderate to high grade refractory properties. The low $\mathrm{Al}_{2} \mathrm{O}_{3}$ content of $\mathrm{NC}$ depicts its non-refractory nature and therefore can be considered only for non-refractory and low heat uses. Free alumina compounds also affect clays by reducing their plasticity because they are non-plastic by nature.

The analysis also reveals the presence of some significant impurities such as the oxides of $\mathrm{Fe}$, $\mathrm{Ti}$ (coloring agents) and the oxides of $\mathrm{Na}$ and $\mathrm{K}$ (fluxing agents). The amount of $\mathrm{Fe}_{2} \mathrm{O}_{3}$ in some of the samples were high and are in the order: NC $(27.52 \%)>$ KC $(5.54)>$ WC $(1.93 \%)>$ MP $(1.39)>$ RC $(0.43 \%)$. High amount of $\mathrm{Fe}$ in clays effect an alteration in their color, reduce the refractoriness which act as weak fluxes and may form scum and visible spots on burnt clay bodies [35]. This explains the reason for the colouring of the natural clays of NC and $\mathrm{KC}$ samples, and this also implies that the samples cannot be used as refractory clays that require less than $5 \% \mathrm{Fe}_{2} \mathrm{O}_{3}$ [31]. However, they can be suitable for the production of building bricks and sewer pipes [9]. RC, MP and WC samples with lower amount of iron content suggests use in the paper, paint, ceramic, sanitary and tile industries [2].

The oxide of Ti follows similar trend as $\mathrm{Fe}_{2} \mathrm{O}_{3}$ in the order $\mathrm{NC}>\mathrm{KC}>\mathrm{WC}>$ MP > RC. Minerals of titaniaact as feeble fluxes at temperatures of $1500^{\circ} \mathrm{C}$ and above [36]. Many kaolinites contain titania along with Fe rich oxides as impurities mainly those found in soils under tropical conditions. The high combined concentrations of $\mathrm{Fe}$ and $\mathrm{Ti}$ in $\mathrm{KC}$ and $\mathrm{NC}$ samples is advantageous in brick making as it gives attractive reddish brown colour appearance [6]. The percentages of $\mathrm{Na}_{2} \mathrm{O}$ are relatively low $(0.12 \%-0.23 \%)$ except in $\mathrm{NC}(1.17 \%)$ that is slightly high. The presence of significant amount of $\mathrm{K}_{2} \mathrm{O}$ in some of the samples can be attributed to the alkali bearing minerals such as muscovite or their sulphates [37]. The effects of all the alkalis in clays are to reduce physical properties such as refractoriness, vitrification temperature, plasticity and shrinkages [38]. 
The impurity oxides of $\mathrm{Ca}$ and $\mathrm{Mg}$ are generally low $(0.07 \%-0.57 \%)$ and are also within acceptable limit for industrial uses as shown in Table 5.

The alumina content of RC (29.34\%) is similar to Ball Clay Tennessee (29.44\%) while the content of silica for RC (62.26\%) is slightly higher than for Ball clay Tennessee (53.96\%). The metal oxides of these clays are also similar as shown in Table 2 and Table 4 respectively. This implies that the clays will be used for similar areas of application. RC and Ball clay Tennessee will have a lower refractoriness compared to flint clay Negev with higher alumina (47.00\%) and lower silica (36.00\%) depicted in Table 4.

Also WC with $37.15 \%$ alumina and $50.15 \%$ silica is similar to China clay Qty having 37.65\% alumina and 46.88\% silica shown in Table 2 and Table 4 respectively. The chemical properties of these clays differ with Building Brick clay Glacial with lower alumina (17.10\%) and higher silica (60.10\%) shown in Table 4. In addition, the clays are also expected to have different application areas.

\subsection{Physical and Fired Properties of Clay Samples}

The results of physical and firing characteristics of the clay samples are presented in Table 3. The $\mathrm{pH}$ (5.20 - 6.40) of the samples indicates that the clays are of acidic origin, appearing as weak acids. This is in agreement that most clay suspensions lay between the $\mathrm{pH}$ range of 4.2 and 7.0 [31]. The particle-size analysis shows that WC has the highest (91.88\%) while NC has the lowest (49.88\%) clay contents. Particle size distribution in this present study is defined in terms of the inherent crystallite size of the minerals present in the clays instead of the grain size produced by a comminution process and natural clays are best defined in terms of their crystallite compositions [39]. The grain size composition of clays control ceramic strength, shrinkage, paper filling/coating and glossiness [40]. The proportions of the clay size materials are in the increasing order of: NC $(49.88 \%)<\mathrm{RC}(67.88 \%)<\mathrm{MP}(73.88 \%)<\mathrm{KC}(84.88 \%)<\mathrm{WC}(91.88 \%)$. Based on the proportion of the ratio of sand: silt: clay textural triangular diagram, all the samples fall within the clay size fractions $(<2 \mu \mathrm{m}$ or $0.002 \mathrm{~mm})$ with the exception of NC which falls within the clay-size fraction of silt-clay [23]. Values above 55\% clay on the triangle are considered heavy clay and this further confirm that all the clay samples except NC are heavy clay deposits.

The clay content for WC and KC samples are close to, while MP, RC and NC are higher than the calculated mineralogical composition shown in Table 1 . This suggests that the muscovite found in MP sample probably has its particle size at the size of the clays, and some of the silt size in the samples could also have their grain size the same as that of the clays thereby resulting in their increased proportion by size analysis [31]. However, silt is considered to be quartz in mineralogical terms, even though their particle sizes differ [41]. The high proportion of clay particles of the kaolins make them suitable for most industrial uses because grain size is an important specification in some industries such as paint, paper, plastics and insecticides [3]. 
Table 3. Physical and fired properties of the clay samples.

\begin{tabular}{|c|c|c|c|c|c|c|c|c|c|c|c|c|}
\hline \multirow[b]{2}{*}{ Sample Clays } & \multicolumn{3}{|c|}{ Particle Size (\%) } & \multicolumn{3}{|c|}{ Plasticity (\%) } & \multicolumn{2}{|c|}{ Shrinkage (\%) } & \multirow[b]{2}{*}{$\mathrm{pH}$} & \multicolumn{2}{|c|}{ Colour } & \multirow{2}{*}{$\begin{array}{c}\text { Refractoriness } \\
\left({ }^{\circ} \mathrm{C}\right)\end{array}$} \\
\hline & Clay & Silt & Quartz & LL & PL & $P_{I}$ & Drying & Firing & & Natural & $\begin{array}{c}\text { Fired } \\
1200^{\circ} \mathrm{C}\end{array}$ & \\
\hline $\begin{array}{c}\text { RahinSho } \\
\text { Clay }\end{array}$ & 67.88 & 24.00 & 8.12 & 57.30 & 25.45 & 33.68 & 1.10 & 1.65 & 6.0 & $\begin{array}{l}\text { Whiter } \\
\text { than N9 }\end{array}$ & $\begin{array}{l}\text { Whiter } \\
\text { than N9 }\end{array}$ & $>1500$ \\
\hline $\begin{array}{c}\text { Major Porter } \\
\text { Clay }\end{array}$ & 73.88 & 18.00 & 8.12 & 45.38 & 29.48 & 15.90 & 1.10 & 2.23 & 6.1 & White N9 & White N9 & $>1500$ \\
\hline $\begin{array}{l}\text { Wereng Camp } \\
\text { Clay }\end{array}$ & 91.88 & 6.00 & 2.12 & 61.15 & 44.05 & 17.20 & 2.23 & 4.99 & 5.6 & $\begin{array}{c}\text { Near White } \\
\text { 5YR 8/1 }\end{array}$ & Near White & $>1500$ \\
\hline Kwi Clay & 84.88 & 14.00 & 4.12 & 63.90 & 28.60 & 33.30 & 1.14 & 2.40 & 5.2 & $\begin{array}{l}\text { Moderate } \\
\text { Orange Pink } \\
\text { 5YR 8/4 }\end{array}$ & $\begin{array}{l}\text { Moderate Pink } \\
\text { 5R 7/4 }\end{array}$ & $>1500$ \\
\hline Naraguta Clay & 49.88 & 43.00 & 7.12 & 48.03 & 23.50 & 24.53 & 2.22 & 3.30 & 6.4 & $\begin{array}{l}\text { Light brown } \\
\text { 5YR 5/6 }\end{array}$ & $\begin{array}{c}\text { Moderate } \\
\text { reddish brown } \\
\text { 10R } 4 / 6\end{array}$ & Fused at 1300 \\
\hline
\end{tabular}

LL = Liquid Limit; PL = Plasticity Limit; PI = Plastic Index.

Table 4. Chemical analysis of some reference clays.

\begin{tabular}{|c|c|c|c|c|c|c|c|c|}
\hline Oxides (\%) & $\begin{array}{c}\text { China Clay } \\
\text { Qty }\end{array}$ & $\begin{array}{l}\text { Fire Clay } \\
\text { Yorkshire }\end{array}$ & $\begin{array}{c}\text { Building Brick } \\
\text { Clay Glacial }\end{array}$ & $\begin{array}{c}\text { Flint Clay } \\
\text { Negev }\end{array}$ & $\begin{array}{c}\text { Ball Clay } \\
\text { Tennessee }\end{array}$ & $\begin{array}{c}\text { (Belpahar } \\
\text { Refractory Clay } \\
\text { India }\end{array}$ & $\begin{array}{l}\text { Residual Kaolin } \\
\text { Ibadan }\end{array}$ & $\begin{array}{c}\text { Kankara Clay } \\
\text { Katsina }\end{array}$ \\
\hline $\mathrm{SiO}_{2}$ & 46.88 & 56.60 & 60.10 & 36.00 & 53.96 & 50.00 & 63.20 & 44.09 \\
\hline $\mathrm{Al}_{2} \mathrm{O}_{3}$ & 37.65 & 26.90 & 17.10 & 47.00 & 29.34 & $31-33$ & 25.61 & 38.67 \\
\hline $\mathrm{Fe}_{2} \mathrm{O}_{3}$ & 0.88 & 1.70 & 5.40 & 1.20 & 0.98 & 3.5 & 1.52 & 1.13 \\
\hline $\mathrm{TiO}_{2}$ & 0.09 & 1.30 & 1.20 & 3.00 & - & 1.38 & 0.22 & 2.21 \\
\hline $\mathrm{Na}_{2} \mathrm{O}$ & 0.21 & 0.22 & 0.70 & 0.30 & 0.12 & \multirow{2}{*}{$1.36-2.0$} & 0.24 & 0.36 \\
\hline $\mathrm{K}_{2} \mathrm{O}$ & 1.61 & 1.26 & 2.70 & 0.30 & 0.28 & & 1.75 & 0.52 \\
\hline $\mathrm{CaO}$ & 0.03 & 0.20 & 3.70 & 0.20 & 0.37 & 0.61 & 0.10 & 1.20 \\
\hline $\mathrm{MgO}$ & 0.13 & 0.30 & 2.80 & 0.20 & 0.30 & 0.38 & 0.05 & 0.15 \\
\hline LOI & 8.00 & 1.26 & 6.40 & 13.00 & 14.01 & $9-14$ & 13.50 & 14.43 \\
\hline
\end{tabular}

Source: [45].

Table 5. Specification of some industrial clays.

\begin{tabular}{cccccccccc}
\hline Oxide \% & Plastics & Paints & $\begin{array}{c}\text { Rubber Paper } \\
\text { Textile }\end{array}$ & Ceramics & Refractory Bricks & Brick Clay & Tiles & Sanitary Wares & $\begin{array}{c}\text { Table } \\
\text { Wares }\end{array}$ \\
\hline $\mathrm{SiO}_{2}$ & 45.78 & $45.30-47.90$ & 44.90 & 45.90 & 67.50 & $51-70.00$ & 70.00 & 54.00 & 46.0 \\
$\mathrm{Al}_{2} \mathrm{O}_{3}$ & 36.46 & $37.90-38.40$ & 32.35 & $33.50-36.10$ & 26.00 & 25.44 & 19.00 & 30.00 & 31.00 \\
$\mathrm{Fe}_{2} \mathrm{O}_{3}$ & 0.28 & $13.40-13.80$ & 0.43 & 0.60 & $0.50-1.20$ & 2.40 & 1.60 & 1.40 & 1.10 \\
$\mathrm{TiO}_{2}$ & - & 13.80 & - & 0.03 & - & & 1.60 & 1.20 & 0.90 \\
$\mathrm{Na}_{2} \mathrm{O}$ & 0.25 & $0.20-0.35$ & 0.14 & 1.60 & 1.50 & 3.50 & 0.5 & 0.50 & 0.40 \\
$\mathrm{~K}_{2} \mathrm{O}$ & 0.25 & $0.40-1.00$ & 0.28 & 1.60 & $1.10-3.10$ & - & 2.0 & 3.10 & 2.20 \\
$\mathrm{CaO}$ & 0.50 & $0.03-0.25$ & $\mathrm{Tr}$ & 0.50 & 0.30 & 0.20 & 0.2 & 0.30 & 0.40 \\
$\mathrm{MgO}$ & 0.04 & $0.20-0.30$ & $\mathrm{Tr}$ & 0.40 & 0.19 & 0.70 & 0.4 & 0.40 & 0.40 \\
$\mathrm{LOI}$ & - & & & 12.40 & & & 5.40 & 8.80 & \\
\hline
\end{tabular}

Source: [45]. 
The plasticity index of the clay samples ranged between $15.90 \%$ to $33.30 \%$ (Table 3 ) and this indicates that the clay samples are of low and medium plasticity. The order of the plasticity index are as follows: RC (33.68\%) > KC $(33.30 \%)>\mathrm{NC}(24.53 \%)>\mathrm{WC}(17.20 \%)>\mathrm{MP}(15.90 \%)$. These values fall within the characteristic plasticity range for kaolinites $(10 \%-60 \%)$ as observed on the plasticity clay identification chart [42]. Depending on the finest size and cation exchange characteristics of the particle size, the plasticity may vary from high to low and most natural clays are complex mixtures of kaolinites with hydrous mica, primary mica, and quartz, along with traces of other minerals [43]. The presence of these in addition to the kaolinites will greatly modify the plasticity of the clays. Chemical nature of the surfaces of clay minerals and their ability to hold water films that act as lubricants, also influence plasticity [44]. This explains the the probable reasons why the plasticity index of RC and $\mathrm{KC}$ clays are high with values above $33 \%$; NC clay is moderate with $24.53 \%$, while MP and WC are slightly above $15 \%$. The presence of appreciable amount of muscovite-an alkali-bearing mineral and quartz (Table 1) which are non-plastic in character, further confirm the low plastic index in MP sample. MP and WC clays are likely to exhibit low-dry strength, indicating low moisture content. The more plastic a clay, the more water it will tolerate without becoming fluid. The extent of this property depends on factors such as specific surface area, size finest, exchangeable cations, composition of the particles and the influence of organic colloids [31].

The average liquid limit ranges from $45.38 \%$ to $63.90 \%$. The values for NC and MP are $48.03 \%$ and $45.38 \%$ respectively. This shows that the clays can be worked through limited range of water content which is a vitalproperty in the ceramic and paper industries, where the behaviour of the clay-water mixture is important [45]. The plastic limit of clays indicates the minimum amount of water required for clays to become plastic. The highest plastic limit (44.05\%) in WC sample could be attributed to the high proportion of the clay material in the deposit. Generally, these clays are fine grained; well crystallized/ordered kaolinite and so have low to moderate plasticity and is important during the blending, moulding and drying stages of the clay [31].

The results of the drying and firing shrinkages for all the samples in Table 3 are quite low. The drying shrinkage ranged from $1.10 \%$ to $2.23 \%$ while the firing ranged from $1.65 \%$ to $4.99 \%$. The low shrinkages as compared with China clays $(10 \%-13 \%)$ fired at $1280^{\circ} \mathrm{C}$ could be due to the high amount of quartz in the clays. The presence of free quartz in clays reduces shrinkages and the low shrinkage values could be attributed to the probable fact that the samples were not heated to the vitrification temperature of $1280^{\circ} \mathrm{C}$ [46]. However, the highest shrinkages observed in WC with $2.33 \%$ and $4.99 \%$ for drying and firing shrinkages respectively could be due to the high proportion of the clay material. These have more pore spaces contained in the minerals which gradually become filled with molten material, and which on cooling solidify to form glass [35]. Low shrinkages are required in ceramics and heavy clay products. 
The colour determination on the natural and fired clays is important in certain industries and it is also an essential requirements. Most kaolin clay deposits like China clays occur naturally as white, while others as fired white. Deviation from that is an indication of the presence of some impurity materials such as iron, cobalt or copper compounds [2]. The colour test result reveals that RC and MP samples retained their white colours after firing as well WC. KC and NC clays show slight colour change from moderate orange to moderate pink and light brown to reddish brown respectively. This coloration is due to the presence of high $\mathrm{Fe}$ and $\mathrm{Ti}$ oxides and they give pleasant colours in the production of bricks and pottery [26]. The white and near white-burning colours of RC, MP and WC samples make them suitable for the manufacture of white wares, refractories, paper and paint [47].

The refractoriness of the samples except $\mathrm{NC}$ is as high as $1500^{\circ} \mathrm{C}$ and it's an indication of a good refractory property. Clays that could be used as fireclays must not fuse below $1500^{\circ} \mathrm{C}$ and must be one above $1600^{\circ} \mathrm{C}$ [34]. NC sample fused at $1300^{\circ} \mathrm{C}$ and therefore cannot be considered as fireclay. This is attributed to the low alumina content, high proportion of fluxing $(\mathrm{Na}, \mathrm{K}, \mathrm{Ca}$ and $\mathrm{Mg}$ ) and colouring agents (Fe, Ti) as revealed by the chemical analysis in Table 2 .

Comparison of the clays mineral compositions with some well-known clay deposits (Table 4) indicates that the WC clay is well over the values of some reference and commercial clays but similar to Kankara and Ibadan kaolins, while KC clay is similar to China clay and is within NAFCON recommended for kaolin clays as shown in Table 1 . The values of RC, MP and NC are lower than the reference clays largely due to the high amount of quartz and muscovite found in these deposits. Nevertheless, these clays have indicated high potentials for various industrial applications for kaolins minerals [47].

Also, a comparison of the clay samples in terms of their chemical compositions with some selected indigenous and foreign clays (Table 4) shows that RC falls within fall Yorkshire fire clay, Tennessee ball clay and Ibadan residual Kaolin. It is also observed that $\mathrm{WC} \mathrm{Al}_{2} \mathrm{O}_{3}$ contentis within the same range with Qty China clay, Negev flint clay and Kankara clay, except that $\mathrm{SiO}_{2}$ content is slightly higher. The result of $\mathrm{KC}$ composition falls within the Indian refractory clays but also has a slight higher content of $\mathrm{Fe}_{2} \mathrm{O}_{3}$. The variations observed in the oxide concentrations from one sample to the other suggest the differences in the environment of the geological formation of the clays and the associated impurities at the location of the sample deposits [2].

The chemical compositions of the clay samples in Table 2 are also compared to some industrial clays shown in Table 5. It is observed that RC falls closely within the values of refractory bricks and sanitary wares applications while MP clay has $\mathrm{Al}_{2} \mathrm{O}_{3}$ content similar to required values for uses in plastics and rubber, paper and textile industries. However, the deposit contains slightly higher $\mathrm{SiO}_{2}$. The results of WC sample closely agree with the values for applications in the plastics, paints and ceramics industries. The values of $\mathrm{KC}$ sample has composi- 
tion similarly for use in table ware though it has slightly higher $\mathrm{Fe}_{2} \mathrm{O}_{3}$ and $\mathrm{TiO}_{2}$ contents, while NC composition is also similar in application for tiles and brick clays making. Generally, the clay samples in the present study have favourably met the requirement for the different industrial uses as shown in Table 5.

\section{Conclusion}

The results of the mineralogical, chemical and physical properties show that all the samples are suitable for various industrial uses. The proportion of the kaolinite for Wereng camp and Kwi clays met the standard specification for kaolin by NAFCON. The chemical composition as well as the physical characteristics also revealed that these clays compare favorably with the specifications of some industrial and reference clays. Each sample deposit has industrial potentials. The naturally white colour of RahinSho and Major Porter clays make them suitable for paper, paint, rubber/plastic, white-wares (sanitary/dinner wares) and refractories productions. Also processing RahinSho and Major Porter to remove sand, $\mathrm{Fe}$, Ti oxides to the desired levels and required size of the minerals could increase their application in paper, plastic/rubber; fertilizer production and even in pharmaceutical. Wereng camp clay with a near-white colour and high proportion of clay-size particles can be successfully used for paint, tiles, sanitary-ware and refractories production. Kwi clay deposit can be used for the production of low grade paint, sewage-pipes, clay bricks and pottery while Naraguta clay deposit's is suitable in the production of clay bricks and sewer pipesdue to the high concentrations of $\mathrm{Fe}_{2} \mathrm{O}_{3}, \mathrm{TiO}_{2}, \mathrm{~K}_{2} \mathrm{O}$; moderate plasticity and low shrinkages.

\section{Conflicts of Interest}

The authors declare no conflicts of interest regarding the publication of this paper.

\section{References}

[1] Tony, C., Bruce, T. and Bob, B. (1999) Mineral Commodity Report 20-Clays. Institute of Geological and Nuclear Sciences.

[2] US Geological Survey (USGS) (1999) Environmental Characteristics of Clays and Clay Mineral Deposits. Information Handout. http://minerals.er.usgs.gov/minerals/pubs/commodity/

[3] Murray, H.H. (2010). http://www.scribed.com/doc.30129755/clays-uses

[4] Jock, A.A., Muhammad, A.A.Z., Abdulsalam, S., El-Nafaty, U.A. and Aroke, U.O. (2018) Surface Modification of Low-Cost Bentonite Adsorbents-A Review. Particulate Science and Technology.

[5] Meseguar, S., Jordan, M.M., Pardo, F. and Sanfeliu, T. (2011) Geology and Application of Clays Used in Castellon Ceramic Cluster (NE, Spain). Journal of Geography and Geology, 3, 132-139.

[6] Attah, L.E. (2010) Physico-Chemical Properties and Industrial Potential of Some Clay Deposits in Calabar Area, South Eastern Nigeria. Global Journal of Environ- 
mental Sciences. http://www.readperiodicals.com/201001/2307422941.html

[7] Asamoah, R.B., Nyankson, E., Annan, E., Agyei-Tuffour, B., Efavi, J.K., Kan-Dapaah, K., Apalangya, V.A., Damoah, L.N.W., Dodoo-Arhin, D., Tiburu, E. K., Kwofie, S.K., Onwona-Agyeman, B. and Yaya, A. (2018) Industrial Applications of Clay Materials from Ghana (a Review). Oriental Journal of Chemistry, 34, 1719-1734. https://doi.org/10.13005/ojc/340403

[8] Vieira, M.G.A., Almeida Neto, A.F., Gimenes, M.L. and Silva, M.G.C. (2010) Sorption Kinetics and Equilibrium for the Removal of Nickel Ions from Aqueous Phase on Calcined Bofe Bentonite Clay. Journal of Hazardous Materials, 177, 362-371. https://doi.org/10.1016/j.jhazmat.2009.12.040

[9] Murray, H.H. (2007) Development in Clay Science 2. Applied Clay Mineralogy. Elsevier.

[10] Emofurieta, W.O., Ogundirin, T.O. and Imeokpai, E.G. (1994) Mineralogical, Geochemical and Economic Appraisal of Some Clay and Shale Deposits of South Western and North Eastern Nigeria. Journal of Mining and Geology, 30, 157-159.

[11] Irabor, P.S.A. (2002) Physical and Chemical Investigation on Some Nigerian Kaolinite Clays For Use in the Ceramics and Allied Industries. Nigerian Journal of Engineering Research and Development, 1, 54-59.

[12] Odo, J.U. and Nwajagu, C.O. (2003) Possible Application of Eha-Alumona Clay Deposit in the Production of Refractories and Ceramic Ware. Proceedings of the Nigerian Materials Congress and Meeting of the Nigerian Materials Research Society at Conference Hall, Engineering Materials Development Institute, Akure, 12-14 November 2003, 109-111.

[13] Akpokodje, E.G., Etu-Efeofor, J.O. and Olorunfemi, B.N. (1991) The Composition and Physical Properties of Some Ceramic and Pottery Clays of Southern-Eastern Nig. Journal of Mining and Geology, 27, 1-8.

[14] Attah, L.E., Oden, M.I. and Ibok, U.J. (2001) Brick Forming Properties of Odukpani clay Deposits from Physical, Mechanical and Mineralogical Studies. West Africa J. Res. Develop. Educ., 8, 93-98.

[15] Attah, L.E. (2008) The Composition and Physical Properties of Some Clay of Cross Rivers State, Nigeria. African Research Review, 2, 84-93. https://doi.org/10.4314/afrrev.v2i1.41026

[16] Omowunmi, O.J. (2000) Characterisation of Some Nigerian Clay as Refractory Materials for Furnace Lining. Nigerian Journal of Engineering Management, 2, 1-4.

[17] Raw Materials Research and Development Council (2001) Multi-Disciplinary Task Force Report of Techno-Economic Survey on Non-Metallic Mineral Products Sector.

[18] National Metallurgical Development Centre (2008) Data Bank of Raw Materials for the Metallurgical Industry. AB Enterprises Ltd., Kaduna.

[19] Osabor, N.V., Okafor, C.P. and Ayi, A.A. (2009) Characterization of Odukpani, South Eastern Nigeria. African Journal of Pure and Applied Chemistry, 3, 79-85.

[20] Joint Committee on Powder Diffractogram Standard (1980) Mineral Powder Diffraction File. Centre for Diffraction, Data, Parklane.

[21] Okafor, C.P., Osabor, N.V. and Ayi, A.A. (2009) Characterization of Odukpani, South Eastern Nigeria. African Journal of Pure and Applied Chemistry, 3, 79-85.

[22] Jock, A.A., Ayeni, F.A., Jongs, L.S. and Kangpe, N.S. (2013) Development of Refractory Bricks from Nigerian Nafuta Clay Deposit. International Journal of Materials, Methods and Technologies, 1, 189-195. 
[23] Ibitoye, A.A. (2008) Laboratory Manual on Basic Soil Analysis. 3rd Edition.

[24] American Society for Testing and Materials (2010) 10 Standard Tests Methods for Liquid Limit, Plastic Limit and Plasticity Index of Soils. https://kashanu.ac.ir/Files/D\%204318\%20-\%2000\%20\%20_RDQZMTG_.pdf

[25] American Society for Testing and Materials (1990) Linear Shrinkage and Coefficient of Thermal Expansion of Chemical Resistance Mortars Grouts. http://www.roadauthority.com/Standards/?id=dc3c58bc-a8f9-4b16-b3bc-df8acb6d6 c6a

[26] Hassan, S.B. (2005) Modern Refractories-Production, Properties, Testing and Applications. Timo Press, Zaria.

[27] Edwin, N.G. (1980) Geological Society of American Rock-Color Chart Committee Book. Boulder.

[28] Emofurieta, W.O. (1988) A Comparative Study of Two Kaolin Deposits in Southwestern Nigeria. Journal of Mining and Geology, 24, 15-20.

[29] Huber, J.M. (1985) Kaolin Clays. Huber Cooperation (Clay Division), Georgia.

[30] National Fertilizer Company of Nigeria (1985) Tender Document for the Supply of Kaolin from Nigeria Source.

[31] Grimshaw, R.H. (1980) The Chemistry and Physics of Clays. 4th Edition, John Willey and Sons, New York.

[32] Santisteban, J.I., Mediavilla, R., Silvino, C. and Martinez, P.E. (2004) Loss on Ignition: A Qualitative or Quantitative Methods for Organic Matter and Carbonate Mineral Content in Sediments. Journal of Paleolimnology, 32, 287-299. https://doi.org/10.1023/B:JOPL.0000042999.30131.5b

[33] Lujan, M.J. and Ary, T.S. (2014) Crystalline Silica Primer. https://minerals.usgs.gov/minerals/pubs/commodity/silica/780292.pdf

[34] Jock, A.A., Ayeni, F.A., Ahmed, A.S. and Sullayman, U.A. (2013) Evaluation of the Refractory Properties of Nigerian Ozanagogo Clay Deposit. Journal of Minerals and Materials Characterization and Engineering, 1, 321-325. https://doi.org/10.4236/jmmce.2013.16048

[35] Ouahabi, E.M., Daoudi, L., Vleeschouwer, D.F., Bindler, R. and Fagel, N. (2014) Potentially of Clay Raw Materials from Northern Morocco in Ceramic Industry: Tetouan and Meknes Areas. Journal of Minerals and Materials Characterization and Engineering, 2, 1-20. https://doi.org/10.4236/jmmce.2014.23019

[36] Maslennikova, G.N., Khalilullova, R.A. and Platov, Y.T. (1999) Identification of Iron Compounds in Clay-Containing Materials. Springer, 56, 48-51. https://doi.org/10.1007/BF02681406

[37] Mermut, A.R. and Cano, A.F. (2001) Base-Line Studies of the Clay Minerals Soc. Source Clays: Chemical Analysis of Major Elements. Clay and Clay Minerals, 49, 381-386.

[38] Grim, E.R. and Kodama, H. (2013) Clay Minerals. http://www.britannica.com/EBchecked/topic/120723/clay-mineral

[39] Syvitski, J.P.N. (2007) Principles, Methods and Application of Particle Size Analysis. Cambridge University Press, Cambridge. http://www.cambridge.org/9780521364720

[40] Talabi, O.A., Ademilua, L.O. and Akinola, O.O. (2012) Compositional Features and Industrial Application of Ikere Kaolinite, South Western Nigeria. Research Journal in Engineering and Applied Sciences, 1, 327-333. 
[41] Guggenheim, S. and Martin, R.T. (1995) Definition of Clay and Clay Minerals. Journals Report of the AIPEA/CMS Nomenclature Committees, 43, 255-256.

[42] Bain, J.A. (1971) Clay Minerals: A Plasticity Chart as an Aid to the Identification and Assessment of Industrial Clays. Inst. of Geo. Sciences, 64-78.

[43] Kogel, J.E. (2006) Industrial Minerals and Rocks: Commodities, Markets and Uses. https://books.google.com.ng/books?hl=en\&lr=\&id=zNicdkuulE4C\&oi=fnd\&pg=PR 9\&dq=Kogel,+J.E.+(2006)+Industrial+Minerals+and+Rocks:+Commodities,+Mark ets+and+Uses.\&ots=Nkr9AZF9 $x 7 \&$ sig $=\mathrm{Ct} 4 \mathrm{tmVcM} 7 \mathrm{pIhm}-\mathrm{K} 35 \mathrm{XmqbycTM} 94 \&$ redi r_esc=y\#v=onepage\&q=Kogel\%2C\%20J.E.\%20(2006)\%20Industrial\%20Minerals\%2 0and\%20Rocks\%3A\%20Commodities\%2C\%20Markets\%20and\%20Uses.\&f=false

[44] Ayari, F., Srasra, E. and Trabelsi, A.N. (2007) Effect of Exchangeable Cations on the Physico-Chemical Properties of Smectites. Surface Engineering and Applied Electrochemistry, 43, 369-378. https://doi.org/10.3103/S1068375507050110

[45] Daspan, R.I., Yakubu, J.A. and Taiwo, A.O. (2009) A Preliminary Chemical and Physical Assessment of the Kuba Kaolin Deposit, Jos Plateau (North-Central Nigeria). Continental Journal of Earth Sciences, 4, 1-11.

[46] Johari, I., Said, S., Hisham, B., Bakar, A. and Ahmad, Z.A. (2010) Effect of the Change of Firing Temperature on Microstructure and Physical Properties of Clay Bricks from Beruas (Malaysia). Science of Sintering, 42, 245-254. https://doi.org/10.2298/SOS1002245J

[47] Murray, H.H. (1991) Applied Clay Science. Overview-Clay Minerals Applications. 379-395. http://www.sciencedirect.com/science 